\title{
“Um lugar fora de lugar": a mulher e o sertão em Maria Valéria Rezende
}

Juliana Santini ${ }^{1}$

Ela, afinal, acreditava, mais do que eu!, me sacudiu no lusco-fusco da madrugada, Vai, sai desse buraco, isso não é para ti, tu só não esquece da gente. Obedeci, sem resistência.

Maria Valéria Rezende, em Quarenta dias

A reflexão aqui proposta tem lugar em uma problematização que se coloca ante a recorrência, na ficção brasileira contemporânea, de narrativas de estrada que fazem uso da figura da viagem na composição de personagens que ora partem do espaço do sertão à procura de melhores condições de vida nas grandes metrópoles, ora retornam a ele, tentando restabelecer um elo - quase sempre subjetivo - que se perdeu na primeira viagem. Soma-se à partida e à chegada um terceiro movimento, aquele que coloca em cena os deslocamentos que se circunscrevem aos caminhos do próprio sertão, seja em peregrinações religiosas, seja no transporte do gado ou em andanças de personagens que transitam de uma estrada a outra.

Não são poucos os exemplos dessa ocorrência. Na literatura, o romance Galiléia, publicado em 2008 por Ronaldo Correia de Brito, traz três primos que viajam de Recife aos Inhamuns, no interior do Ceará, percorrendo o caminho que leva de volta à fazenda da infância, cujo nome dá título ao livro, onde o avô ainda vive. Aqui, Adonias, o narrador que mistura o tempo presente à memória do passado e aos segredos da família, é a voz que imprime uma dimensão subjetiva ao espaço. O romance contém os principais temas do conjunto da ficção de Ronaldo Correia de Brito, que em entrevista ao jornal $O$ Globo, na ocasião do lançamento do volume de contos Amor das sombras, afirma ter composto uma tetralogia do sertão, com uma "unidade de atmosfera" que se sustenta justamente

${ }^{1}$ Doutora em estudos literários e professora da Universidade Estadual Paulista Júlio de Mesquita Filho (Unesp), Araraquara, SP, Brasil. Eorcid.org/0000-0001-5267-7230. E-mail: jsantini@fclar.unesp.br 
pela representação do universo sertanejo. No conjunto das 37 narrativas que enfeixam essa tetralogia, o que se tem é um sertão dividido entre a manutenção de elementos, costumes e modos de vida arcaicos e uma modernização precária, insuficiente, acentuando o contraste entre urbano e rural pela via daquilo que o sertão não é ou, em outra chave, assumindo um tom de saudosismo pelo que o sertão deixou de ser. Nos dois casos, o sertão parece se constituir sob um signo negativo: ainda não / já não mais.

No cinema, O céu de Suely, lançado em 2006 sob direção de Karim Aïnouz, pode servir como uma espécie de síntese do fluxo entre os distintos polos de atração que compõem essa produção. Hermila, no início da narrativa, chega a Iguatu, no interior do Ceará, trazendo consigo Mateuzinho, o filho pequeno. Trata-se de um retorno: anos antes, Hermila havia partido de Iguatu para São Paulo, onde o pai da criança agora ficava para resolver pequenos assuntos, com a promessa de, em poucos dias, rumar ao encontro da família. É necessário pouco tempo para que Hermila perceba-se abandonada com o filho, depois do sumiço de Mateus, que deixa de dar notícia e não faz a mesma viagem. Para Hermila, o sertão é expulsivo: sem trabalho e sem se reconhecer na pequena cidade, ela rifa o próprio corpo - uma noite no céu com Suely - e com o dinheiro arrecadado compra uma passagem rodoviária para Porto Alegre. O filme termina com a personagem dentro do ônibus e a imagem da estrada, na qual a placa de trânsito anuncia, ironicamente, a partida: "Aqui começa a saudade de Iguatu".

Contrapostos, esses dois exemplos apontam para potenciais diferenças nos significados relacionados ao deslocamento nessas narrativas. No romance, o protagonista é um homem, médico bem-sucedido, que retorna ao sertão para uma visita; no filme, Hermila, mulher, não se fixa em nenhum espaço, e o retorno para o sertão é uma marca do fracasso do sonho de viver em São Paulo. Diante disso, ao trânsito - ou à imobilidade - de personagens, interessa a proposição de indagações como: quem se desloca? Qual a origem e o destino desses personagens? De que maneira o sertão, como ponto de partida ou como ponto de chegada, assume significados diversos nesse contexto?

A questão que aqui se coloca diz respeito a personagens femininas que se deslocam - ou não - pelo sertão e à representação da mulher nesse contexto. Embora se parta de um panorama amplo 
dessa produção, considerando inicialmente o protagonismo masculino em narrativas que, nos últimos anos, acabam por, em larga medida, manter o paradigma de representação firmado na tradição literária de matriz sertaneja, essa discussão centra-se no romance Outros cantos, de Maria Valéria Rezende. Nesse caso, está em questão o modo como a construção das personagens Maria e Fátima articula-se ao deslocamento empreendido pela primeira e à imobilidade da segunda, construindo um par opositivo capaz de revelar, por contraste, o lugar ocupado por duas mulheres distintas, uma delas detentora da voz que constrói um relato de si e do sertão.

\section{"Falar de mulheres"}

Em diferentes entrevistas, sobretudo depois de ter recebido o Prêmio São Paulo de Literatura por Galiléia, Ronaldo Correia de Brito propõe que o seu sertão é feminino. Isso porque muitas são as mulheres que permeiam suas narrativas: Cícera Candóia, Eufrásia Meneses, Maria Caboré e Inácia Leandro são, de fato, mulheres fortes, que o sertão embruteceu, a quem a terra e o sol ensinaram a interpretar a passagem do tempo e a enfrentar a espera. E talvez espera seja mesmo uma chave para compreender muitas dessas personagens: em silêncio, elas aguardam o retorno do marido, a peleja do dia terminar, a dor da traição a mainar; em silêncio, maturam o veneno, planejam a vingança, aguardam a noite com uma faca sob o travesseiro.

O próprio autor chama atenção para o silêncio de suas personagens femininas em Galiléia e para a dimensão feminina do universo sertanejo representado no conjunto da ficção que produziu até 2010, data de entrevista concedida ao blog da Saraiva por ocasião do lançamento de Retratos imorais:

Praticamente todos os personagens são homens, quer dizer, as mulheres quase não falam. As únicas mulheres que falam são uma contadora de histórias, que diz apenas uma frase, e a outra personagem é um fantasma. As vozes femininas são ouvidas apenas por trás das paredes ou através da televisão, são vozes da televisão. No entanto, todo o romance é construído para celebrar uma epifania do feminino (Brito, 2010, s.p.). 
A fala de Ronaldo Correia de Brito traz para o primeiro plano uma discussão que envolve aspectos relativos ao domínio da representação, base mesma da própria literatura. No caso específico da produção a que se refere nessa entrevista - o volume Faca, de 2003, Livro dos homens, de 2005, e Galiléia -, o interesse em "falar do feminino" articula dois objetos de representação - a mulher e o sertão. Diante disso, há que se considerar, primeiramente, que a retomada do sertão em narrativas dos últimos 20 anos mobiliza uma imagem que se construiu como uma matriz ao longo da literatura brasileira desde o Romantismo. Não se pode falar em "sertão" na ficção contemporânea sem que, em uma espécie de palimpsesto, os significados reiterados ou desconstruídos nos sucessivos projetos estéticos e ideológicos que deram azo à representação de regiões interioranas no amplo conjunto da cultura brasileira apareçam como marcas rasuradas por um novo processo de escrita.

Sob esse aspecto, e diante da proposição de que "o Nordeste, assim como o Brasil, não são recortes naturais, políticos ou econômicos apenas, mas, principalmente, construções imagéticodiscursivas, constelações de sentido" (Albuquerque Júnior, 2011, p.343), a construção de um sertão feminino não deixaria de esbarrar nos traços semânticos essencialmente masculinos historicamente reiterados nas diferentes representações do mundo sertanejo: o código de honra que, na insuficiência ou corrupção de qualquer aparato legal, rege as relações - a honra do homem que se lava com sangue, por exemplo -; o vaqueiro encouraçado e a força física dispendida para domar a caatinga; a violência do cangaço (aparte concedido para a figura de Maria Bonita).

$\mathrm{Na}$ ordem patriarcal que rege esse imaginário, a literatura regionalista brasileira inscreveu grande parte de suas personagens femininas ao lado de ou sob figuras masculinas. Mesmo nos casos em que a mulher institui-se como o polo da razão, do bom senso ou da sensibilidade, é no contraponto com o homem, e não como sujeito, que ela se constrói: basta lembrar de Sinhá, Amélia e Adriana, as esposas da tríade masculina que estrutura o romance Fogo morto, ou mesmo de Sinhá Vitória, em Vidas secas.

Nos raros casos em que a personagem feminina subverte essa ordem e se torna protagonista, sua composição revela uma ambiguidade marcada pela demonização da mulher que não se 
submete ao jugo do homem. Margarida Reginaldo de Oliveira Barros é Guida, do romance Dona Guidinha do poço, escrito por Manuel de Oliveira Paiva no final do século XIX e publicado postumamente, em 1952, com o trabalho de recuperação e de edição de Lúcia Miguel Pereira. Guida é uma matriarca, fazendeira dona de si e de todos - inclusive do marido, de cujo assassinato ela é a mandante. Generosa, honesta e doce no princípio, a personagem assumirá a ambivalência da crueldade e da monstruosidade da mulher adúltera que tem como amante o sobrinho do marido. No livro de 1903, de Domingos Olímpio, a ambiguidade que marcará a protagonista - algo entre os valores da heroína romântica e o determinismo da perspectiva naturalista - aparece já no título do romance Luzia-Homem. Mesmo que de modo breve e superficial, também vale lembrar que, para vingar a morte do pai e entrar no bando jagunço, Diadorim é mulher que se traveste.

No interior de formações discursivas em que o sertão é masculino e másculo -, as personagens femininas de Ronaldo Correia de Brito emergem de vozes também masculinas e, embora apareçam reiteradamente na revelação de um universo de opressão e violência, não superam a condição de silêncio imposta pela fala de um outro. Donana, personagem presente em todos os seus livros - o "fantasma" que fala em Galiléia -, dá a medida desse silenciamento que, ao mesmo tempo em que cala, erige a mulher a uma dimensão de tabu. No conto "Faca", de 2003, Donana, "redonda de gorda de tanto chupar umbu" (Brito, 2003, p. 29), é assassinada por seu marido, Domísio Justino, que forja o adultério da esposa para então matá-la e poder se casar com "uma mulher bonita e jovem" (Brito, 2003, p. 31), que conhecera em outras terras, transportando gado. A personagem é retomada no primeiro conto de Livro dos homens, dois anos mais tarde, na narrativa que conta a história de um corpo desfigurado acolhido pelos habitantes de Monte Alverne, o corpo de Domísio Justino, morto pelos irmãos de Donana como forma de vingança.

Silenciada, Donana não deixa de funcionar na revelação de uma lógica patriarcal violenta e opressora, mas também não se liberta do fato de ser a fala de um outro. Na observação dessa característica das mulheres de Ronaldo Correia de Brito, uma outra constatação vem à tona: as mulheres que habitam o universo do sertão no conjunto de sua ficção não se deslocam de um espaço a outro, permanecem imóveis, de 
modo que não empreendem nenhuma jornada espacial que funcione, objetiva ou metaforicamente, como movimento interior ou como experiência de outros mundos, que se contraponham a um sertão posto como clausura. A exceção é Antônia, do conto "Milagre em Juazeiro".

É curioso que as grandes jornadas apareçam em deslocamentos empreendidos por personagens masculinos, sejam eles homens do sertão - sertanejos que viajam transportando gado, negociando terras ou mesmo migrando para a cidade -, sejam eles sujeitos que se deslocam da cidade para o interior. Nos dois casos, o deslocamento pode ser observado em significados que se complementam: de um lado, em uma perspectiva material, como marca de uma mobilidade diretamente relacionada aos "fazeres" cotidianos, que delimitam muito claramente de que modo, na lógica de organização do sertão, os papeis permanecem rigidamente postos. De outro lado, em uma chave simbólica em que o trânsito associa-se à articulação entre tempo e espaço, sustentando a metáfora do encontro consigo mesmo - para centrarmos no conceito de cronotopo da estrada (Bakhtin, 1998) -, restringe-se ao homem a possibilidade de uma experiência da qual se projete uma fala sobre si e sobre o outro calcada na lógica do encontro, do enfrentamento, do reconhecimento ou da disjunção.

No contexto da ficção brasileira dos últimos anos, em que o sertão aparece atrelado à experiência da viagem, poucas são as personagens femininas cuja construção está articulada ao deslocamento. No romance As mulheres de Tijucopapo, publicado em 1982 por Marilene Felinto, a narrativa constrói-se por meio do deslocamento da narradora Rísia, "marcada por duas partidas: do escaldante Recife da infância para a esperança de vida melhor em São Paulo; da frustração de São Paulo rumo à utopia de uma revolução de mulheres guerreiras em Tijucopapo, terra onde teria nascido sua mãe" (Schmidt, 2008, p. 22). Em que pese essa dimensão utópica da revolução quando tomada ao lado do contexto de publicação do romance, interessa considerar, de antemão, que Rísia não apenas se particulariza pelos sucessivos deslocamentos que empreende, mas também por ser detentora da fala que se narra, o que aqui interessa na medida em que, estruturalmente, parece vincular, na narrativa, a figura da estrada à composição da voz narrativa em primeira pessoa.

Simone Pereira Schmidt, em artigo de 2008, propõe que o deslocamento e a viagem estão ligados ao ato de assumir a posição de 
sujeito da própria fala na construção de Rísia e, também, de Ponciá Vicencio, no romance homônimo de Conceição Evaristo, de 2003, enfatizando a perspectiva de que "Rísia e Ponciá se constituem nessa busca de um outro lugar, que não sabem bem qual é, mas que certamente as mobiliza" (Schmidt, 2008, p.26). Nas duas narrativas, a estrada percorrida passa pelo sertão como ponto de partida ou de chegada, e esse movimento tem como direção a perspectiva de uma vida melhor fora do universo sertanejo, que se desenha como um território expulsivo. Diferentemente, Donana, na ficção de Ronaldo Correia de Brito, permanece à espera, comendo umbu e depositando no próprio corpo a penitência e a dor de um silenciamento que, no limite, também é imobilidade. Na comparação, reafirma-se a proposição de que o trânsito e a experiência do deslocamento funcionam como uma espécie de operadores instrumentais na atribuição de voz às personagens femininas - hipótese que orienta esta discussão.

\section{Outra voz}

É em Outros cantos, de Maria Valéria Rezende, que se poderia encontrar uma síntese entre a personagem feminina que se desloca por diferentes espaços e aquela que permanece sem mobilidade. No romance, Maria é a narradora que viaja em um ônibus em direção a Olho d'Água, povoado do interior onde esteve 40 anos antes, como professora contratada por um dos vereadores do local para trabalhar na alfabetização de adultos. A narrativa se constrói pela oscilação de tempos engendrada no relato de Maria: o presente da narração, em que a personagem permanece na estrada, no interior do veículo, vendo o sertão pela janela e observando os passageiros que embarcam ou desembarcam conforme chegam a seus destinos; e o presente dos fatos que narra, instituindo um intervalo de quatro décadas entre a experiência vivida e o momento da fala, que embaralha a vida em Olho d'Água a flashes de uma memória que evoca outros cantos, como Argélia e México, onde também esteve. No presente, Maria viaja para dar uma palestra a pedido de um sindicato de agricultores; no passado, foi de São Paulo ao sertão como militante de esquerda infiltrada em um programa de educação do governo militar, na tentativa de conscientizar o trabalhador e contribuir para a construção de uma revolução do proletariado. 
Para a reflexão que aqui se está realizando, interessa observar a relação que se cria entre as personagens Maria e Fátima, a mulher que acolheu a professora recém-chegada em Olho d'Água e lhe ensinou os meandros da vida no sertão. A cena em que se narra o primeiro contato com o povoado dá a medida das posições que cada uma ocupará nessa relação:

Lembro-me, no meu primeiro encontro com aquele povo, em torno das banheiras fumegantes: assim que respondi mais uma vez "Maria, meu nome é Maria", ouvi "Eu sou Fátima". Havia uma única mulher a remexer uma caldeira de tinta, entre os homens mudos. Socorreu-me, com solidária coragem falou comigo, explicou-me cada coisa que eu via, pegou-me pela mão e me levou a ocupar seu posto enquanto ia olhar seu fogo, seu feijão, seus meninos, abriu um espaço para mim entre aquela gente que não me havia chamado, não precisava de mim. Um lugar fora de lugar, como o dela, no qual seríamos duas a receber no rosto o vapor ardente subindo da tina, a tingir o fio como um homem, os braços dela fortes como os deles, os meus, por certo mais jovens, incapazes de mover o peso das meadas no mesmo ritmo, quase inúteis para sustentar longamente o esforço que só a vergonha de desistir me fazia aguentar (Rezende, 2016, p.24).

Fátima representa a mulher que, no sertão, está à espera. $\mathrm{O}$ marido partira há anos, em busca de trabalho, com o intuito de guardar dinheiro para a compra de um tear. Dele, as notícias que recebia eram apenas as peças do equipamento, que ela guardava uma a uma, como se cada nova parte colocasse diante de seus olhos um conjunto que, quando completo, o traria de volta. Diferentemente da figura de Donana, porém, a espera de Fátima é outra: o papel que desempenha no trabalho de tingimento dos fios, marcadamente masculino, inscreve a personagem em um lugar na ordem material, econômica mesmo, de sua própria sobrevivência:

Ela, Fátima, ficou, seca, quem sabe se viúva. Por um tempo incontável. Mulher sem tear e sem homem, assumiu trabalho de macho, tingindo fio no lugar de um ou outro impedido por doença, luto, viagem ou devoção. Urdia teares de outras famílias, traçava varandas ao fim do dia. Por centavos, ou por um alguidar de milho, ou por seis paus de macaxeira, duas rolinhas, seus meninos caçando lenha no mato, sempre 
arranhados, os pés estrepados, por centavos. Mais pobre que todos, Fátima (Rezende, 2016, p. 36).

E a força de Fátima sustentará também o tempo de espera de Maria no sertão: com a demora no cumprimento da promessa do vereador que a contratou, a professora arrefece em sua disposição, com a certeza de que o material escolar não viria, o ordenado prometido também não e, como consequência, não veria se concretizar o despertar da consciência política pela educação. E enquanto esperava, acostumando-se à pouca água, ao trabalho duro, à escassez de comida e ao calor, Maria teve de aprender a lógica das relações geridas no cotidiano sertanejo.

Mais do que material, é de ordem simbólica o aprendizado da personagem na temporada que permanece em Olho d'Água, sob a tutoria cuidadosa da amiga que, de dentro do sertão, o escancara, uma vez que ela, Maria, estava fora de lugar. Exemplar, nesse sentido, é o episódio em que Maria, ao ouvir uma briga em que o marido surrava sua esposa, intercedeu por ela e foi vítima de um ataque da própria mulher, que defendeu o direito do homem de surrá-la. Chegando à casa de Fátima, estarrecida e apavorada, é a partir da fala da amiga que Maria percebe a naturalização da violência, legitimada em um contexto de opressão e de machismo extremos:

Estaquei, estarrecida, e quase fui abatida pela paulada que atingiu um tamborete ao meu lado e me despertou as pernas para saltar de lado e sair correndo pela porta afora, pelo caminho todo, até chegar, ofegante, de volta à casa de Fátima. Arriei num banco, encostada à parede, mal respirando, minha amiga e a pirralhada à minha volta, espantados, "O que foi? Assombração? Cobra? $\mathrm{O}$ que foi?". Só depois de um grande caneco d'água adoçada com rapadura fui capaz de contar, entre soluços, a cena toda. "Ixe! E você foi se meter nisso, menina? É doida? Nunca ouviu dizer: em briga de marido e mulher, ninguém mete a colher?" Quis protestar, mas Fátima insistiu, "É costume, ninguém morre disso não. $\mathrm{O}$ meu homem nunca me bateu, é doce como mel, mas a gente não tem nada a ver com o que se passa dentro da casa dos outros. Aprenda" (Rezende, 2016, p. 125).

O jogo de vozes que se cria, aqui, é emblemático de uma estrutura narrativa que coloca em paralelo os pontos de vista de duas mulheres: de um lado, aquela que, naquele momento, vinha 
de outro espaço - de São Paulo - e, com um olhar de quem não pertence ao sertão, tentava interferir em sua lógica; de outro, a que nunca saíra de sua terra e, embora também estivesse fora de lugar, fazendo trabalho de "macho", reproduzia a rigidez de um padrão que era incapaz de questionar.

Sob esse aspecto, a articulação de dois tempos - o da viagem de ônibus e o da experiência vivida - é fundamental para que essa visada em perspectiva se construa. Aqui, é preciso levar em conta que, assim como acontece com outras narrativas de estrada, a composição e o desenvolvimento da personagem Maria dependem da relação intrínseca que estabelece com a própria figura da estrada, tanto do ponto de vista de um processo de formação e de reconhecimento desenrolado no interior do trânsito, quanto no que diz respeito à dimensão espacial que, atrelada ao tempo da viagem, submete o personagem a territórios outros. Tempo e espaço agregam-se na medida em que o primeiro entranha-se à matéria do segundo, estando a apreensão, a delimitação e a constituição da memória temporal diretamente determinadas por uma ou várias referências espaciais - no limite, como sugere Bachelard (1993), o espaço retém o tempo em seus alvéolos.

Em sua viagem de retorno ao sertão, dentro do ônibus, Maria enovela o tempo passado a um espaço e a um tempo que, agora, são outros. O sertão que se mostra às margens da rodovia não é mais aquele que se engendra em sua fala, passado costurado a um presente visto pela janela ou observado nos trejeitos daqueles com quem compartilha o veículo. No romance, os momentos em que a fala da narradora se refere ao presente são separados de suas memórias por um espaçamento maior entre os parágrafos e são consideravelmente mais curtos quando tomados ao lado dos episódios por ela narrados. A narração do tempo em que viveu no sertão ao lado de Fátima, seus filhos e os outros moradores de Olho d'Água alonga-se em capítulos maiores, que dão a medida de uma fala impulsionada por uma ruptura com o presente, evidente na medida em que, ao intercalar os dois registros temporais, a narradora mostra-se, inclusive, em seu desejo de romper com o tempo presente e de se manter submersa em suas lembranças:

Por mim, ficaremos aqui mesmo ainda por muito tempo para eu continuar a reviver meu primeiro sertão, não quero 
vê-lo desaparecer agora, sabe Deus por quanto tempo ou para sempre. Finalmente, entre muitos gestos de adeus, o carro retoma sua marcha, agora lenta e ondulante pelas depressões e calombos dos desvios da estrada em obras, e volto a rememorar a comovente história de Maria do Socorro (Rezende, 2016, p.117).

Alguns pontos merecem destaque nesse trecho: Maria viaja em um ônibus cujo destino é o sertão e observa, no ponto de chegada de cada passageiro, o retorno de quem um dia deixou esse mesmo sertão para trás. Esse fluxo migratório realiza-se em sentido contrário àquele que se dava hegemonicamente à época de sua temporada em Olho d'Água, já que "lá não se costumava chegar, de lá só se ia embora". Essa inversão no sentido do deslocamento humano articula-se à percepção da narradora, que nota, desde o início, as mudanças que rasuram o universo sertanejo de outrora: as casas que, à beira da estrada, mostram pelas portas abertas a mobília pobre e a televisão ligada; o "autismo digital" dos três jovens isolados do mundo por seus fones de ouvido. O desejo de permanecer no interior do veículo marca, nessa oscilação entre presente e passado, a recusa inicial de Maria, que não se reconhece nesse presente de "já não mais".

Para Marília Amorim (2010), que analisa a obra do diretor iraniano Kiarostami, nas narrativas de estrada, a figura do carro assume papel importante na medida em que se constitui como um elemento ambivalente, que atua como veículo do deslocamento e, também, como instrumento que delimita a dimensão espacial em que se circunscrevem os sujeitos em trânsito, sempre imóveis quando se considera a estaticidade de quem, no interior do automóvel, permanece à mercê do movimento realizado pelo veículo. A ambivalência realiza-se no contraste criado entre mobilidade e fixidez: enquanto a imagem do carro representa a metáfora do deslocamento entre espaços distintos, seu interior determina a clausura do sujeito que olha pela janela e, do exterior, conhece apenas a paisagem ou o enquadramento do espaço percorrido. ${ }^{2}$

Tomada a partir das considerações de Michel de Certeau (2014) a respeito da experiência de um viajante em um trem, a relação que se

${ }^{2}$ Discuti essa questão um pouco mais detidamente em texto sobre o filme Mutum, de Sandra Kogut (Santini, 2012). 
cria entre os elementos estruturadores da situação que engendra a narrativa - ônibus, estrada, sertão, insulamento da personagem no interior do veículo - determina a construção de uma subjetividade rasurada, como se vem discutindo, por tempo e espaço, mas também pela imposição do ato de narrar: "A vidraça e a linha férrea repartem de um lado a interioridade do viajante, narrador putativo e, do outro, a força de sê-lo, constituído em objeto sem discursos, poder de um silêncio exterior" (Certeau, 2014, p.179). É o processo de narração que põe em movimento a percepção do tempo presente em contraste com o passado, paradoxalmente ativado pelos quadros que se desenham do outro lado da janela, fronteira que, pela transparência, separa Maria desse novo sertão ao mesmo tempo em que fragmenta o relato da memória e o torna permeável ao que está fora do ônibus.

No caso específico do romance de Maria Valéria Rezende, essa ambivalência espacial corresponde à dualidade temporal que fundamenta a narrativa e, no limite, o processo de narração como um todo. Do lado de fora, o sertão contemporâneo evocando a memória de outrora, emoldurado pela janela do ônibus e pelo olhar de Maria para esse presente; do lado de dentro, a narradora se protege desse novo sertão e se rende ao presente - inclusive no uso do tempo verbal - nos pequenos trechos em que é chamada à realidade por um solavanco, um defeito no ônibus ou um passageiro ouvindo música.

Essa força do presente é determinada, ainda, pelas condições materiais da viagem. As sucessivas paradas do ônibus para o embarque de passageiros que aguardam à beira da estrada ou em pequenos povoados - prática comum no interior do Brasil, em que o embarque e desembarque de passageiros nem sempre passam por terminais rodoviários regulamentados - ou, ainda, a necessidade de descer do ônibus e aguardar a fiscalização da polícia sobre uma pedra no acostamento rompem o insulamento e fragilizam a metáfora do veículo como cápsula temporal. No limite, o que se coloca é algo que envolve o processo de representação do sertão na narrativa contemporânea: a imagem do presente impõe, invariavelmente, o sertão de outros tempos.

\section{Uma voz fora da parede}

Maria se rende a certa euforia por esse novo tempo quando se dá conta de que, nessa nova viagem, a utopia da mudança que se 
concretiza pela conscientização do trabalhador se renova. Ao final da narrativa, já se sabe que a empolgação da jovem professora militante foi interrompida pela perseguição dos militares, 40 anos antes, justamente no momento em que Olho d'Água se organizava para as aulas. A última viagem, "movida a sonhos", não se encerra, e o romance termina com a narradora avistando as luzes da cidade onde deverá desembarcar para ser ouvida - o que merece destaque nessa reflexão sobre o deslocamento e a personagem feminina articulada ao sertão.

Viajando, Maria conheceu Olho d'Água, a Argélia, o México e tantos outros cantos. Ao receber voz para falar de si como personagem da narrativa, Maria passa a ocupar, no conjunto da ficção que, nos últimos anos, retoma o sertão, um lugar fora de lugar - expressão que ela repete duas vezes em seu relato. Do ponto de vista do processo de representação, Maria não é uma personagem do sertão e, portanto, poder-se-ia dizer que sua perspectiva não é "de dentro" desse espaço. Ocorre, porém, que seu relato mistura a dimensão do eu à apreensão do outro justamente na relação que cria com Fátima: se as andanças de Maria fizeram com que ela conhecesse a amiga, foi justamente a imobilidade de Fátima que deu a ela o conhecimento suficiente para que ensinasse Maria a sobreviver no sertão. Para além disso, dona do relato, Maria é a voz que Fátima jamais poderia ter, enclausurada que esteve na lógica das relações patriarcais do sertão, em que ela desempenhou papel de homem, mantendo-se circunscrita à condição de mulher.

Diante de uma narradora que se coloca como uma "deslocada", cabe uma indagação diante de um segundo "lugar fora de lugar". A escrita do sertão ou sobre o sertão se constitui, na história da literatura brasileira, de forma hegemonicamente masculina exceção feita a Rachel de Queirós. Se o sertão se desenha na construção de um imaginário ligado a signos masculinos, também é verdade que o cânone reitera uma perspectiva que se associa à fala de homens. Nos últimos 20 anos, se a representação do sertão já se coloca como um lugar outro em uma produção que é essencialmente urbana, a construção de personagens mulheres que detêm a voz e se deslocam, por meio de seu olhar e de sua fala, para construir uma narração de si mesmas e da condição de outras mulheres não deixa de ser um lugar a ser construído. 
É importante considerar, nesse ponto, que Outros cantos, ao colocar uma personagem mulher em movimento e a ela atribuir a voz que conduz a narração, cria uma lógica peculiar no interior das narrativas de estrada quando essas são tomadas como um gênero específico, cujas bases podem ser situadas na gênese do road movie e na permeabilidade da literatura aos seus elementos paradigmáticos. Discutindo essa relação da narrativa literária com a forma cinematográfica do road movie, Samuel Paiva (2014) aponta o romance On the road, de Jack Kerouac, como emblemático da incorporação desses recursos, salientando como um traço fundamental desse processo a manutenção do protagonismo dado aos homens, o que em larga medida circunscreveu o road movie - e também o road novel - à narração das experiências de um sujeito masculino em crise. No contexto em que o gênero constitui suas bases no suporte cinematográfico, a figura da estrada alia-se à representação de um desejo de liberdade masculino, seja no questionamento das normas sociais por meio da figura de um outsider, seja no trauma criado pelas duas grandes guerras na associação do homem a engrenagens e aparatos de destruição: “O road movie seria uma espécie de resposta a esse trauma, trauma refletido na incapacidade do sujeito masculino de lidar com a fixidez da casa e do trabalho convencionais" (Paiva, 2014, p. 79).

Em que pese a necessidade de relativização do lugar ocupado pelo feminino em algumas realizações daquilo que já se pode pensar como uma história do gênero road movie, há que se notar que, na literatura e no cinema brasileiros, as narrativas de estrada irão, desde os anos 1960, sofrer o influxo de determinações históricas e culturais locais e manter, no protagonismo da viagem, a figura masculina. A publicação de Jorge, um brasileiro, de Oswaldo França Júnior, em 1967, dá a medida dessa permeabilidade das narrativas de estrada a questões nacionais, colocando-se como "herdeiro de uma tradição modernista brasileira que registra a geografia de um país onde personagens se deslocam tentando a sobrevivência, em busca de trabalho" (Paiva, 2009, p. 5).

Note-se, diante disso, que a ficção dos últimos 20 anos parece amenizar os vínculos dessa relação entre a viagem e o trabalho, de modo que o deslocamento assume caráter mais subjetivo mesmo nos casos em que a estrada é margeada por um espaço cuja 
materialidade se impõe na seca, na dificuldade de sobrevivência ou na marginalização econômica. Juntamente com o romance já citado de Ronaldo Correia de Brito, Nossos ossos, publicado em 2013 por Marcelino Freire, constitui exemplo dessa guinada subjetiva que, se por um lado, desvincula o enredo do cotidiano de trabalho - a condução do gado, o transporte de cargas -, por outro, não deixa de pôr o sertão como elemento ao qual se associa a própria motivação do trânsito. Na narrativa de Marcelino Freire, Heleno é um dramaturgo que retorna de São Paulo ao interior Pernambuco conduzindo, em espírito e ao lado do motorista de um carro funerário, o corpo do gigolô que, como ele, migrara para a capital paulista anos antes, em busca uma vida melhor. Expulsivo na sua constituição material, o sertão é aqui o lugar do reencontro, casa para a qual se retorna já sem vida, à procura de abrigo.

Uma vez que a subjetivação do relato ganha espaço, há que se notar que é justamente a composição da voz narrativa em primeira pessoa que dá azo e suporte ao processo de internalização do dado exterior - a estrada, o sertão. Na estrutura do road novel, a narração autodiegética $^{3}$ funciona na articulação entre a experiência do deslocamento e o ato de narrar, de modo que a mudança a que se submete o sujeito ao longo da viagem, que sobrepõe tempos ao longo do trajeto pelo espaço, transforma-se em história de si mesmo e do outro, aquele - ou aqueles - com quem se cruza pelo caminho: "o deslocamento no espaço é o indício primeiro, o mais óbvio, da mudança; ora, quem diz, diz mudança. O relato também se alimenta da mudança; nesse sentido, viagem e relato aplicam-se mutuamente" (Todorov, 2006, p. 231).

No romance de Maria Valéria Rezende, esse imbricamento entre deslocamento e narração sofre, como se vem discutindo, duas outras determinações: a atribuição de voz a uma personagem feminina que viaja por um espaço específico, o sertão. Enquanto Donana é narrada por um homem em Galiléia e por um narrador em terceira pessoa nos contos de Ronaldo Correia de Brito, Maria atua como "filtro quantitativo e qualitativo que rege a representação narrativa" (Reis e Lopes, 1988, p. 251), uma vez que nela também se centraliza a

3 "Entidade responsável por uma situação ou atitude narrativa específica: aquela em que o narrador da história relata as suas próprias experiências como personagem central dessa história" (Lopes e Reis, 1988, p. 118). 
focalização dos acontecimentos que sustentam a diegese. Sendo assim, é sua experiência na estrada 40 anos antes e agora, incluindo o olhar que lança sobre os vilarejos que se acumulam ao cruzar o sertão presente, que dá a Maria a possibilidade de narrar, o que lhe garantiu, inclusive, a empatia e acolhida dos habitantes de Olho d'Água em sua primeira visita - vale lembrar que mais do que a alfabetização, que pouco sentido fazia naquele espaço, aos sertanejos interessava as histórias que a forasteira contava, casos de outros cantos em que estivera ou de livros que lera, relatos de outras viagens.

Diferentemente de Fátima, a Maria cabe o domínio da palavra e, por isso, por meio de sua voz a narrativa se constrói como um "percurso de espaço" (Certeau, 2014, p. 182). A se considerar que "espaço é o efeito produzido pelas operações que o orientam, o circunstanciam, o temporalizam e o levam a funcionar em unidade polivalente de programas conflituais ou de proximidades contratuais" (Certeau, 2014, p. 184), a viagem funciona como elemento estruturante no romance, o que significa dizer que Maria narra porque se desloca, mas também que o sertão representado na narrativa é feminino porque a experiência nele circunscrita também o é.

Rísia, no romance de Marilene Felinto, e Ponciá Vicêncio, de Conceição Evaristo, viajam em busca de outro lugar - o que coloca no cerne do deslocamento para fora do sertão a revelação de uma condição material de marginalização no interior da ordem patriarcal. Maria, partindo para dentro do sertão e, 40 anos depois, retornando a ele, revela essa mesma condição no contraste que cria com Fátima, imóvel. Ocorre, porém, que a natureza do relato que sustenta a narrativa de Maria Valéria Rezende, também ele em trânsito, amplia o espectro na medida em que cria a necessidade de narrar o outro - Fátima, inclusive -, e de romper seu silêncio depois de ter experienciado o seu lugar.

\section{Referências}

ALBUQUERQUE JÚNIOR, Durval Muniz de (2011). A invenção do Nordeste e outras artes. 5. ed. São Paulo: Cortez.

AMORIM, Marília (2010). Cronotopo e exotopia. In: BRAITH, Beth (Org.). Bakhtin: outros conceitos-chave. São Paulo: Contexto. p. 95-114. 
BACHELARD, Gaston (1993). A poética do espaço. São Paulo: Martins Fontes.

BAKHTIN, Mikhail (1998). Questões de literatura e de estética (a teoria do romance). 4. ed. São Paulo: Editora da Unesp.

BRITO, Ronaldo Correia de (2003). Faca e Livro dos homens. Rio de Janeiro: Alfaguara.

BRITO, Ronaldo Correia de (2005). Livro dos homens. São Paulo: Cosac Naify.

BRITO, Ronaldo Correia de (2008). Galiléia. Rio de Janeiro: Alfaguara.

BRITO, Ronaldo Correia de (2010). Ronaldo Correia de Brito e o sertão entre o universo masculino e o feminino. Entrevista Bruno Dorigatti. Blog da Saraiva, São Paulo. On-line. Disponível em: <https:/ / bit.ly/2MB5zGu>.

CERTEAU, Michel de (2014). A invenção do cotidiano: artes de fazer. 22. ed. Petrópolis: Vozes.

PAIVA, Samuel (2009). A propósito do gênero road movie no Brasil: um romance, uma série de TV e um filme de estrada. Revista Rumores, São Paulo, v. 3, n. 6, p.1-11.

PAIVA, Samuel (2014). O deslocamento do sujeito masculino no sertão contemporâneo: estudos de caso na literatura e no cinema. In: VICENTE, Adalberto Luís; JUNQUEIRA, Renata Soares (Org.). Teatro, cinema e literatura: confluências. São Paulo: Cultura Acadêmica; Editora da Unesp. p.75-92.

REIS, Carlos; LOPES, Ana Cristina M. (1988). Dicionário de teoria da narrativa. São Paulo: Ática.

REZENDE, Maria Valéria (2016). Outros cantos. Rio de Janeiro: Alfaguara.

SANTINI, Juliana (2012). Miguilim, Thiago e a estrada. Casa: Semiótica Aplicada, Araraquara, v. 10, n. 2, p. 1-13. Disponível em: < https:/ / bit.ly/2N8a6Qd>. Acesso em: 8 jul. 2017.

SCHMIDT, Simone Pereira (2008). De volta pra casa ou o caminho sem volta em duas narrativas no Brasil. Estudos de Literatura Brasileira Contemporânea, Brasília, n. 32, p. 21-30.

TODOROV, Tzvetan (2006). A viagem e seu relato. Revista de Letras, São Paulo, v. 6, n. 1, p. 231-244.

Recebido em 25 de julho de 2017.

Aprovado em 21 de janeiro de 2018. 


\section{resumo/abstract/resumen}

\section{“Um lugar fora de lugar": a mulher e o sertão em Maria Valéria Rezende Juliana Santini}

Este trabalho propõe uma reflexão sobre o deslocamento da personagem feminina no romance Outros cantos, de Maria Valéria Rezende. O objetivo é problematizar de que modo a representação do sertão articula-se, na narrativa, à composição de uma protagonista que, sendo mulher, narra sua própria viagem e coloca em perspectiva presente e passado. Entra em questão, nesse caso, não apenas a figura feminina, mas também os significados atribuídos ao sertão na ficção brasileira contemporânea.

Palavras-chave: sertão, deslocamento, feminino, narrativa brasileira contemporânea.

\section{"A place out of place": woman and hinterland in Maria Valéria Rezende}

Juliana Santini

This work proposes a reflection on displacement of the female character in the novel Outros cantos, by Maria Valéria Rezende. The objective is to problematize how the representation of the hinterland articulates itself, in the narrative, into the composition of a protagonist who, being a woman, narrates her own trip and puts in perspective present and past. What is in question, in this case, is not only the female figure, but also the meanings attributed to hinterland in Brazilian contemporary fiction.

Keywords: hinterland, displacement, female character, Brazilian contemporary narrative.

\section{“Un lugar fuera de lugar”: el sertão y la mujer en Maria Valéria Rezende Juliana Santini}

Este trabajo propone una reflexión sobre el dislocamiento del personaje femenino en el romance Outros cantos, de Maria Valéria Rezende. El objetivo es reflexionar de qué modo la representación del sertão se articula en la narrativa, en la composición de una protagonista que, siendo mujer, narra su propio viaje y pone en perspectiva el presente y el pasado. En este caso está en cuestión, no solamente la figura femenina, sino también los significados atribuidos al sertão en la ficción brasileña contemporánea.

Palabras clave: sertão, cambio, femenino, narrativa brasileña contemporánea. 